\title{
DEMAND-SIDE INNOVATION POLICIES AND THE PLANNING OF THE PUBLIC TRANSPORTATION SYSTEM IN THE CITY OF CURITIBA (STATE OF PARANÁ, BRAZIL)
}

\author{
MARIANO DE MATOS MACEDO \& MÁRCIA DE ANDRADE PEREIRA BERNARDINIS \\ Professors of the Postgraduate Program in Urban Planning at the Federal University of Paraná, Brazil
}

\begin{abstract}
The aim of this article is to analyze demand-side innovation policies in urban planning strategies. The article provides an example by evaluating the actions involved in the public transport system adopted by the Municipal Government of Curitiba in Paraná State, Brazil, in the mid nineteen seventies when the Express Bus System (Bus Rapid Transport - BRT) was technically specified, ordered, developed and implemented. It was made compatible with the urban design of a new road system and norms for the use of urban land for the city (Trinary System). In this context, the Express Bus was an innovative solution, as the buses in the city up to that time were known as "truck buses", i.e., a truck chassis with the bodywork of a bus. For the businessmen who operated Curitiba's bus companies, this solution would mean purchasing new buses with completely new models and characteristics. This article discusses the theoretical aspects relative to innovation policies (supply side and demand-side), the urban design of the Trinary System and the technical specification process of the Express Bus.

Keywords: innovation, demand-side innovation policies, planning of the public transportation system, Curitiba (State of Paraná, Brazil).
\end{abstract}

\section{INTRODUCTION}

Traditionally, innovation policies have been associated with supply-side instruments with a view to building competencies in the field of R\&D (lines of funding under favorable conditions; economic subvention; supply of specialized infrastructure and tax breaks). However, in Brazil and overseas, there has actually been an increase in the adoption of demand-side innovation policies (DSIP).

DSIP are a set of instruments for creating, inducing, articulating or increasing demand and/or improving conditions to diffuse innovations in the market, such as public procurement for innovation (PPI), defining new specifications for products, services and processes through standardization and regulation and promoting user-producer interaction.

With this kind of policy, a number of urban planning strategies have increasingly incorporated the Science, Technology and Innovation (ST\&I) vector. The potential of this type of public policy for designing urban planning strategies of this nature has not been explored in detail theoretically and analytically.

The aim of this article is to analyze demand-side innovation policies in urban planning strategies, evaluating the actions involved in the public transport system adopted by the Municipal Government of Curitiba in Paraná State, Brazil, in the mid nineteen seventies when the Express Bus System was developed and implemented.

It should be highlighted that this article was not intended as an exhaustive history of these actions. Furthermore, this analysis was restricted to aspects of an eminently technical nature, not taking into account its determinants of a political and institutional nature.

In this sense, this article was written for a specific purpose, to diffuse the concept of demand-side innovation policies as an instrument of urban planning. 


\section{DEMAND-SIDE INNOVATION POLICIES:}

ANALYTICAL REFERENCE FRAMEWORK

Analyses conducted by the Organization for Economic Cooperation and Development [1] on the theme of DSIP can be referred to for a better understanding of the topic.

According to the OECD [1], the recent focus on DSIP is a result of the finding that, despite advances, supply-side innovation policies (SSIP) are not sufficient when it comes to promoting innovation. Furthermore, current pressures on fiscal budgets have led to growing interest in DSIP with a view to increasing the productivity of public spending, given their potential to boost innovations.

The OECD [1] emphasizes that DSIP, as a complement to SSIP, impose characteristics of a systemic nature on the set of innovation policies. Interest in demand-side innovation policies results from recognizing the importance of feedback connections between supply and demand in the innovation process. This type of policy goes beyond the linear innovation model, usually focused on R\&D, towards a systemic model. In this case, it is the specification of demand that directs resources and competencies to generate innovations (demand pull), with a view to meeting certain social goals or market needs. The focus is on the end rather than the beginning of the innovation chain. In this sense, demand-side innovation policies complement (and do not substitute) supply-side policies (supply push) [1] - Fig. 1.

Edler et al. [2] constitute another important reference for understanding the nature of DSIP. The authors highlight the nature of this kind of policy and its importance as an instrument for guiding the innovation process in order to achieve social goals or meet the strategic targets of public policies. According to Edler et al. [2], the demand-driven approach is based on the specification, creation and support for the demand for innovation. The demand can spur the generation and diffusion of innovations. The justification of this type of policy is based on the following pillars: creating incentives to overcome market failures; encourage innovations with a view to achieving the goals of public

policy strategies (e.g. urban mobility); and promoting the development of innovative businesses (lead markets) in a certain region/country.

Edler [3] presents a typology of DSIP, as follows:

$\rightarrow$ Public procurement for innovation (PPI): PPI “occurs when a public organization places an order for the fulfillment of certain functions that are not met at the moment of the order or call) within a reasonable period of time through a new or improved product" [4];

$\rightarrow$ Definition of new requirements or specifications for products, services and processes through standardization and regulation. Standardization is the "activity that, in relation to existing or potential problems, provides instructions intended for common or repetitive use in order to attain an optimum degree of order in a given context" [5]. Regulation is the "implementation of rules by the public authorities that influence the market and behavior of actors in the private sector" [6]; and

$\rightarrow$ Promoting user-driven innovation.

Going beyond the conceptual dimension to analyze actual cases of DSIP, Kaiser and Kripp [7] understand that, in general, analyses of innovation policies focus on their instruments and do not take into account their political and institutional determinants. Of these determinants, the need to adapt their instruments to current legislation and the technical and operational capability of public institutions to implement this kind of policy deserve to be highlighted. On the institutional plane, Edquist et al. [8] claim that, in DSIP, there is a high degree of tension between legal norms and the need to accommodate informal cooperation relationships related to user-producer interaction, which is inherent to the innovation process. 


\section{Supply push}

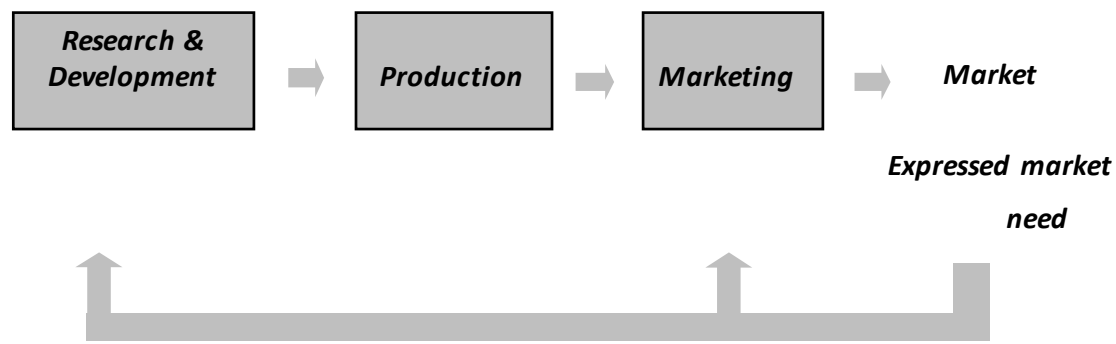

Demand pull

Figure 1: Supply-side and demand-side innovation policies. (Source: Organization for Economic Cooperation and Development. (OECD, 2011, p. 19.)

Table 1: Demand-side innovation policies and urban planning. (Source: Prepared by the authors.)

\begin{tabular}{|c|c|}
\hline $\begin{array}{c}\text { Demand-side innovation } \\
\text { policies }\end{array}$ & Examples focused on urban planning \\
\hline $\begin{array}{l}\text { Public procurement for } \\
\text { innovation }\end{array}$ & $\begin{array}{l}\text { Public procurement for innovation (e.g., acquisition of } \\
\text { innovative traffic monitoring systems); } \\
\text { Concession contracts requiring investments in RD\&I (e.g., } \\
\text { public transport with hybrid vehicles and the selective } \\
\text { collection and treatment of solid waste); } \\
\text { Support for the diffusion of and demand for innovations by } \\
\text { the private sector associated with requirements of RD\&I and } \\
\text { strategic urban planning goals, e.g., tax breaks to help diffuse } \\
\text { electric and hybrid vehicles, and green building benefits } \\
\text { through sustainable constructions; } \\
\text { Local content demands associated with RD\&I requirements } \\
\text { (e.g., LED street lighting from local/regional/national } \\
\text { suppliers). } \\
\text { eGovernment projects and smart cities"; } \\
\text { Urban renewal, redevelopment, and revitalization projects } \\
\text { based on ST\&I, e.g.: specific land use for location of urban } \\
\text { science parks, Knowledge Locations [9], Innovation Districts } \\
\text { [10] and New Century Cities [11]. }\end{array}$ \\
\hline $\begin{array}{l}\text { Definition of new } \\
\text { requirements or technical } \\
\text { specifications for products, } \\
\text { services and processes }\end{array}$ & $\begin{array}{l}\text { Green building standards and labels; regulation of the } \\
\text { diffusion of solar heating in social housing projects; } \\
\text { regulation of energy efficiency and the use of fossil fuels in } \\
\text { public transport fleets. }\end{array}$ \\
\hline $\begin{array}{l}\text { Promoting user-producer } \\
\text { interaction }\end{array}$ & $\begin{array}{l}\text { Partnership between municipal governments and automotive } \\
\text { sector companies to develop electromoblity projects. }\end{array}$ \\
\hline
\end{tabular}

\section{DEMAND-SIDE INNOVATION POLICIES AND URBAN PLANNING}

In keeping with the typology introduced by Edler [3], Table 1 shows examples of DSIP instruments with potential use in urban planning. It should be highlighted that, in all these instruments, there are many possibilities for action by Municipal Authorities. 


\section{DEMAND-SIDE INNOVATION POLICIES AND THE PLANNING OF THE PUBLIC TRANSPORTATION SYSTEM IN THE CITY OF CURITIBA (STATE OF PARANÁ, BRAZIL)}

One of the main references in the history of Curitiba's urban planning is the Preliminary Urbanism Plan, drafted in 1964. According to Wilheim [12], the following directives of this plan deserve to be highlighted:

1. Strengthen two structural roads identified in the existing system in order to structure urban expansion;

2. Through legislation related to land use, encourage the establishment of a denser population along these two roads; and

3. Implement a mass transport system, which could initially be limited to buses using the exclusive bus lane.

With this plan as a reference, the Curitiba Director Plan was passed in 1966, centered on three basic directives that, together, came to guide the growth of the city: the Road System, Land Use and Public Transport.

In the early 1970s, the Institute of Research and Urban Planning of Curitiba (IPPUC) promoted detailed projects with a view to implementing these directives and their effects on the urban design of the city. According to the IPPUC [13], with regard to the "structural roads, land use and public transport", the Trinary System was the solution. This system, structuring the design, is made up of a central lane exclusively for express buses (Bus Rapid Transport - BRT) with the intention of gaining operational velocity. It also has two slow traffic lanes on either side of the central lane, allowing access to shops and houses. One block away from the slow traffic lanes are one-way roads that allow rapid transit to and from the city center (one from the city center to the suburbs and one from the suburbs to the city center). (Figs 2 and 3).

Through the Municipal Government's demand-side policy, this design encouraged technological innovations on buses considered adequate for public transport in the central lane of the Trinary System (express bus).

According to Oliveira [14], the buses in the city up to that time were known as "truck bus. In other words, a truck chassis with the bodywork of a bus: too high, too noisy, not powerful enough for urban transport, small passenger capacity and with only two narrow doors at each end of the vehicle, making it difficult for passengers to move around inside".

With a view to developing the express bus, the IPPUC, in 1972, had already looked at the possibilities of the Uiraquitan project. This was an experimental bus model adapted to urban

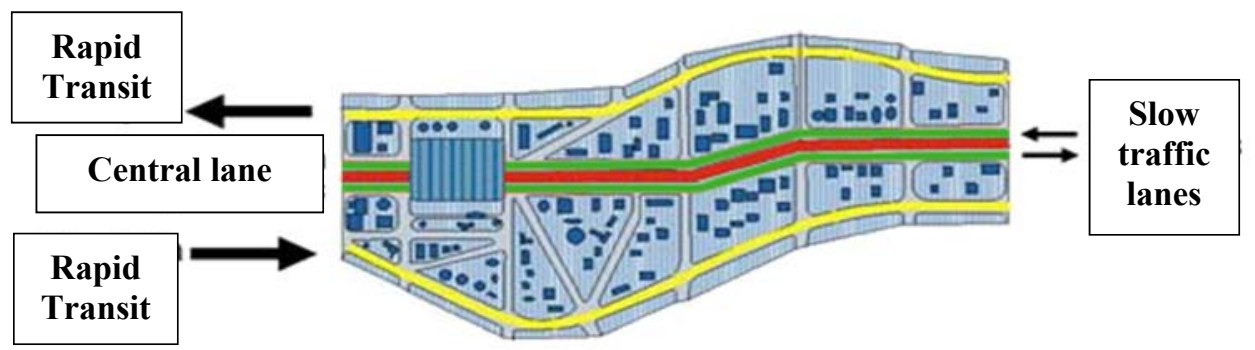

Figure 2: Curitiba's Urban Planning: Trinary System. (Source: IPPUC. History of Urban Planning in Curitiba: http://www.ippuc.org.br/\#.) 


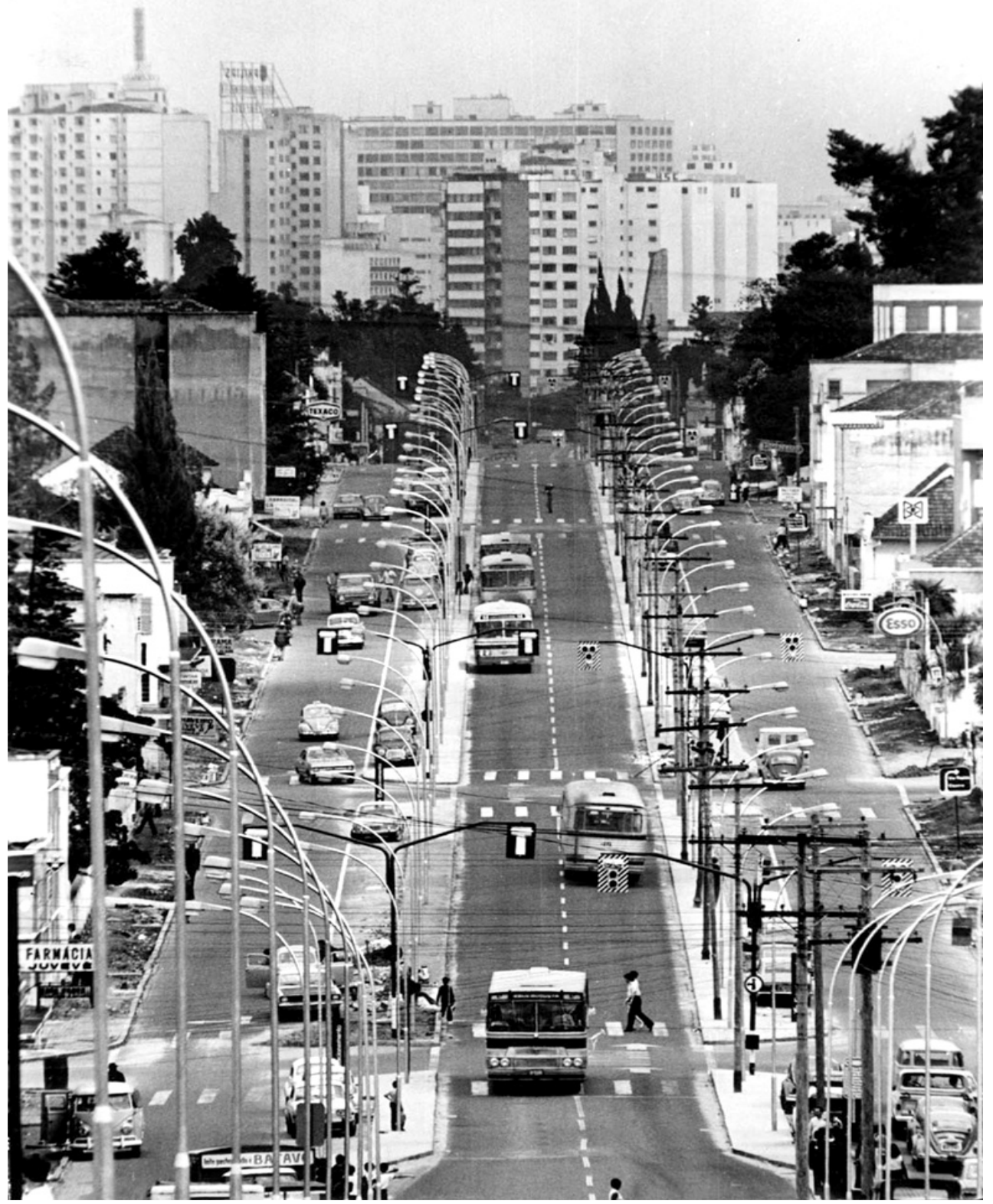

Figure 3: Trinary System of Curitiba in the early seventies: central lane and slow traffic lanes. Traditional style bus at the time. (Source: IPPUC. History of Urban Planning in Curitiba: http://www.ippuc.org.br/\#.) 
conditions, developed by the Department of Vehicle Research (DEPV) of the University of Industrial Engineering (FEI) in São Bernardo Campo, at the time the main center of the automotive industry in Brazil. According to O Estado de São Paulo newspaper [15], on $25 / 03 / 1973$, it was predicted that this bus could "comfortably transport 80 passengers seated longitudinally in two rows of seats", with the "center of gravity lowered (...) improving its stability". An "anti-pollution system in the engine" was also predicted, reducing pollution by $50 \%$. Furthermore, it would be "two tons lighter than other buses", without turnstiles. The driver would be "isolated in a glass booth".

In 1973, the IPPUC, having abandoned the Uiraquitan project, considered by the then CEO of the IPPUC (Rafael Dely) as "essentially technical with no practical application", went on to outline an express bus project using its own technical team: "vehicle specification, suspension, engine, power, gearbox, in other words, a bus made for the city" [16]. Ceneviva [16], one of the technicians on this team, confirms that the design of the express bus was a concept of the IPPUC. According to Oliveira [14], to the "architects" that planned the bus, it had to be a vehicle totally unlike the old "truck bus": "lower in height, with larger windows, three wide doors, high torque engine located at the back, greater passenger capacity, safety devices, etc. For businessmen who operated Curitiba's bus companies, this would mean purchasing new buses with completely new models and characteristics".

In this context, the technical specifications of these new buses "were submitted to national industry (...). Three companies answered the call of the city government: Marco Polo S/A Bus Bodies (from Caxias do Sul); CAIO - American Industrial Bus Company (from São Paulo); and Furcare Manufacturing S/A - Bus Body Industry (also from Caxias do Sul). Marcopolo was awarded the contract (...) to manufacture the new buses for Curitiba" [17]. According to Dely and Oikawa [18], "the traditional manufacturers of bus bodies (Mercedes Benz, Scania and others) declined to work with a chassis designed especially for buses, preferring to continue working with truck chassis. Therefore, another company, Cummins, operating from Salvador, Bahia, offered to provide the chassis" adapted to the express bus model.

Produced by Marcopolo, the express bus ("Veneza Expresso") became operational in the central lane of the North-South Trinary System of the city (running the route from Santa Cândida to Praça Generoso Marques to Capão Raso) on 22/09/1974 (Figs 4 and 5).

The technical specifications of the express bus that went into operation in September of 1974 are not very different from those referred to in the Official Notice published by the Municipal Government of Curitiba on 15/10/1974, quoted by Camargo [17], and in Annex 1 of Decree 787, of 30/09/1974, as follows:

"Due to the need to increase the fleet of vehicles operating in the Express Bus System and considering the need to manufacture appropriate vehicles for this purpose, in accordance with the regulations of Decree 787/74, of 30 September 1974, in Annex 1 of the Regulations for Passenger Transport Services on the Express Buses in the city of Curitiba, companies that manufacture this kind of equipment, in the form of chassis, bus bodies on chassis manufactured by third parties or manufacturers of complete units are invited to present projects for examination and approval for future orders from the operators of the lines in question. Interested parties can obtain further details through direct contact with the IPPUC (Institute of Research and Urban Planning of Curitiba).”

This Annex 1, in the form of a normative instrument typical of demand-side innovation policies, listed the "Characteristics of Vehicles" deemed appropriate for circulation and public transport in the central lane of the Trinary System. 


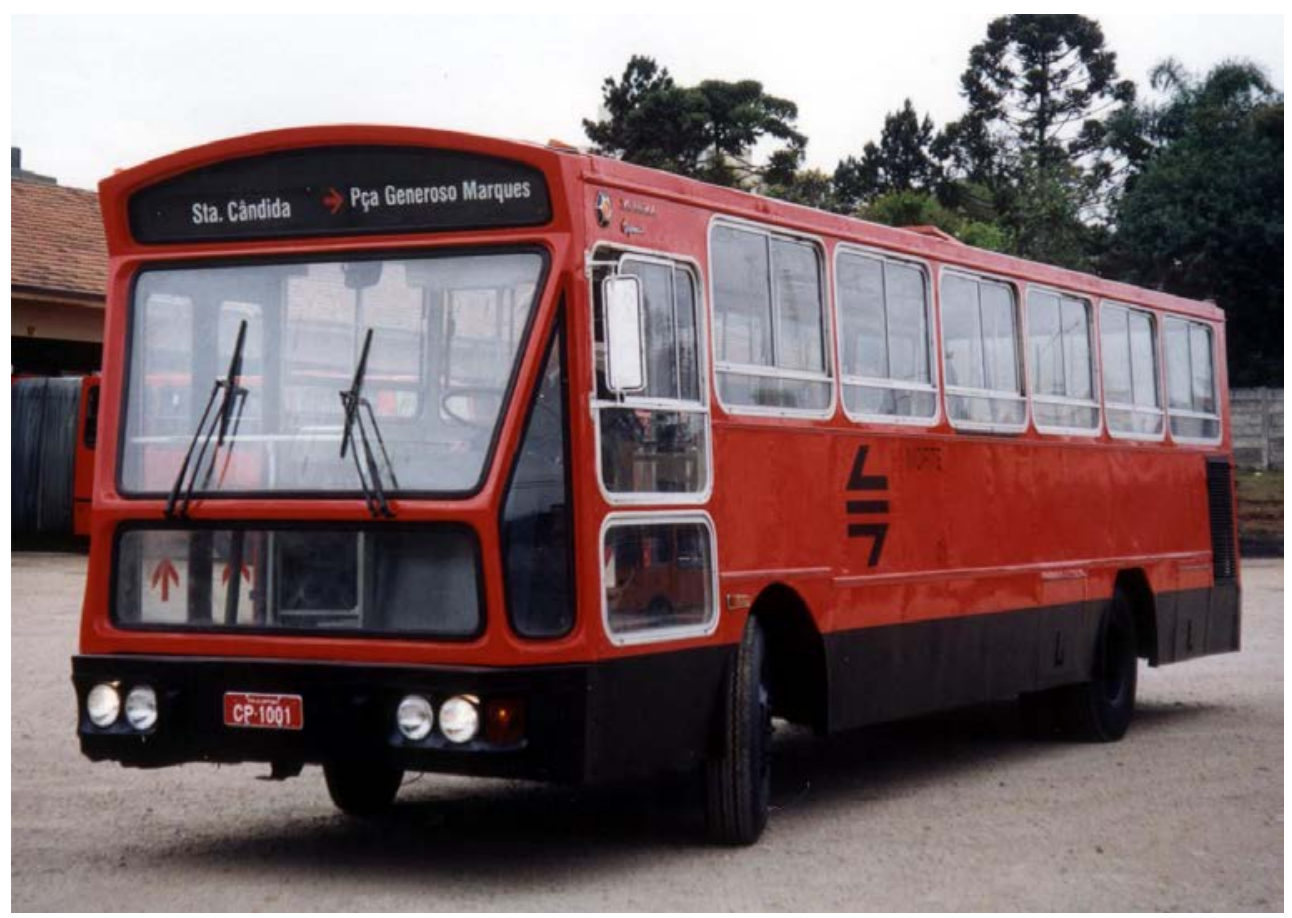

Figure 4: Express bus belonging to the Curitiba Public Transport System in 1974. (Source: http://expressoveneza1974.blogspot.com.br.)

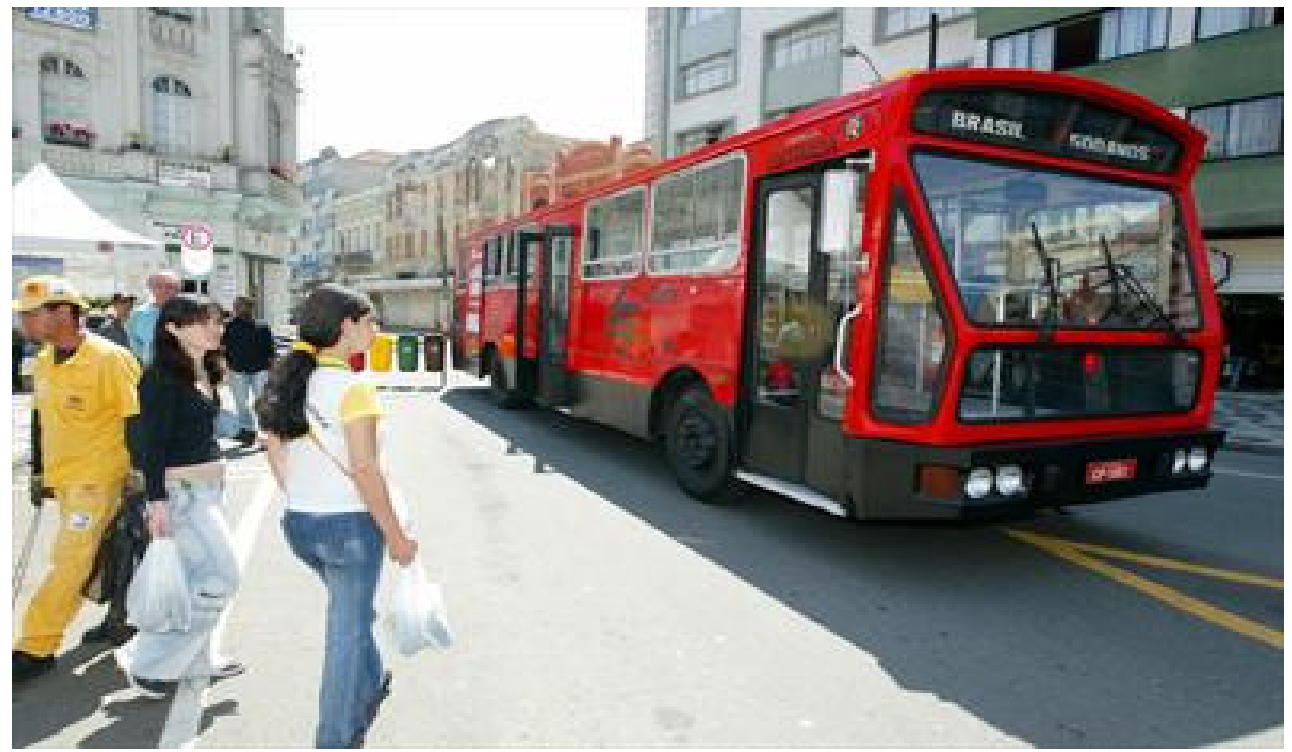

Figure 5: Express bus belonging to the Curitiba Public Transport System in 1974. (Source: http://expressoveneza1974.blogspot.com.br.) 
According to this decree, express buses for public passenger transportation should meet these normative requirements, of which the following deserve to be highlighted:

1. The basic structures of the vehicles, i.e., the set known as the "chassis" or the set of the "gearbox" structure, used in the manufacturing process known as the "monoblock platform", should be projected and manufactured by the manufacturer of the vehicle unit specifically for use on urban buses;

2. Minimum capacity of 35 seated passengers and 50 passengers standing;

3. Microphone system with loudspeakers to announce the names of bus stations and stops;

4. Propulsion system:

a) Propulsion set (engine, gearbox and differential) with acceleration capacity of the vehicle with fuel and passengers to enable an acceleration test on a clear horizontal track from zero (stationary vehicle) to a speed of $50 \mathrm{~km} / \mathrm{h}$, in a maximum time of 16 seconds;

b) Upload capacity of full vehicle to maintain a speed of $50 \mathrm{~km} / \mathrm{h}$;

c) The engine must not run on gasoline;

d) Position of the engine in the rear of the vehicle in a compartment totally isolated from the area destined for passengers;

e) It is advisable to use automatic gears; and

f) Guarantee fuel consumption at a minimum of $2 \mathrm{~km} / \mathrm{liter}$.

5. It is advisable to use "air suspension", and hydraulic steering is compulsory; and

6. Lifespan of 5 years of regular service.

\section{CONCLUSIONS}

The example of the actions for structuring the public transport system adopted by the Municipal Government of Curitiba in the mid nineteen seventies, when the development and implementation of the Express Bus System were adapted to the design of the Trinary System, demonstrates the importance of DSIP in urban planning strategies.

The current techno-economic paradigm of the production of goods and services, focusing on information and communication technologies, meant new possibilities and demands related to the production of urban space. In this context, ST\&I are increasingly becoming a vector of innovative urban solutions, like those listed in Table 1. If the ST\&I vector is highly intense, these solutions and the investment that they imply can multiply their pull impact on levels of production, innovation and the endogenous outcomes of various production chains. In this context, and given the importance of the role of the state in shaping urban space, DSIP instruments (public procurement for innovation, definition of new requirements or technical specifications for products, services and processes and promoting user-producer interaction) tend to assume a prominent role in the agenda of public policies that focus on the development of cities.

It is important to mention that highlighting this role of the state does not imply confusing DSIP with picking winners policies. Picking winners means the prior selection of companies ("national champions"). According to Georghiou [19], in the case of DSIP, their instruments should be operated with a view to an open process from the results of which winners emerge: "here it is the competitive arenas that are being picked, not the firms". In this process, this arena is constructed by the requirements established by PPI, normalization and regulation of the goods and services market or call for proposals for innovation partnerships subject to being accessed by the set of companies. Nevertheless, even considering that in the design of DSIP the choice to be made refers to "the competitive arenas, not the firms", this does not 
mean that these policies are immune to being captured by interest groups ("market flaws") or being affected by "government flaws".

Understanding how DSIP can be captured by "market flaws" or affected by "government flaws" would imply analyzing their determinants of a political and institutional nature. As observed, the analysis conducted in this article was restricted to theoretical aspects and those of a strictly technical nature.

\section{REFERENCES}

[1] OECD - Organisation for Economic Co-Operation and Development. Demand-side innovation policies. [s.1]: OECD; 2011. www.oecd.org/document/61/ 0,3746,en $26493741748078845 \quad 1 \quad 1 \quad 1 \quad 37417,00$ html. Accessed on: 5 Jul. 2018.

[2] Edler, J., Georghiou, L., Blind, K. \& Uyarra, E., Evaluating the demand side: New challenges for evaluation. Research Evaluation, 21(1), pp. 33-47, 2012. DOI: 10.1093/reseval/rvr002.

[3] Edler, J., Review of policy measures to stimulate private demand for innovation: concepts and effects. In: MIOIR-Manchester Institute of Innovation Research (Org.). Compendium of evidence on the effectiveness of innovation policy intervention. MIoIR/Nesta: Manchester, 2013.

[4] Edquist, C., Vonortas, N.S., Zabala-Iturriagagoitia, J.M. \& Edler, J., Public Procurement for Innovation. Edward Elgar Publishing, 2015. www.researchgate.net/ publication/269929143_Public_Procurement_for_Innovation. Accessed on: 5 Jul. 2018.

[5] ABNT. Normalização: definição. www.abnt.org.br/normalizacao/o-que-e/o-que-e. Accessed on: 4 Jul. 2018.

[6] Blind, K., The impact of regulation on innovation. Nesta Working Paper, n. 12/02, Jan. 2012. www.nesta.org.uk/sites/default/files/the_impact_of_regulation_on innovation.pdf. Accessed on: 5 Jul. 2018.

[7] Kaiser, R. \& Kripp, M., Demand-orientation in national systems of innovation: a critical review of current European innovation policy concepts. In: Druid Summer Conference 2010 - Opening up Innovation: Strategy, Organization and Technology, 2010, Londres. Londres: Empirical College London Business School, Jun. 2010.

[8] Edquist, C., Hommen, L. \& Tsipouri, L.J. (eds), Public Technology Procurement and Innovation, Kluwer Academic Publishers, 2000. (Economics of Science, Technology and Innovation, v. 16).

[9] Van Winden, W., Carvalho, L., Van Tuijl, E., Van Haaren, J. \& Van Den Berg, L., Creating Knowledge Locations in Cities: Innovation and Integration Challenges, Routledge, Erasmus University Rotterdam: London, 2012.

[10] Katz, B. \& Wagner, J., The Rise of Innovation Districts: A New Geography of Innovation in America. Metropolitan Policy, Brookings Institution, May, 2014.

[11] Joroff, M., Frenchman, D. \& Rojas, F., New Century City Developments: creating extraordinary value, Massachusetts Institute of Technology, Third Global Workshop: November 9-11, 2009, Seoul, Korea.

[12] Wilheim, J., Espaços e palavras, Projetos Editores Associados: São Paulo, 1985. (Cadernos Brasileiros de Arquitetura, n. 15).

[13] IPPUC. História do planejamento urbano de Curitiba. www.ippuc.org.br/\#. Accessed on: 5 Jul. 2018.

[14] Oliveira, D., Curitiba e o mito da Cidade Modelo. Editora UFPR: Curitiba, 2000. 
[15] O Estado de São Paulo. Para Curitiba solução está no ônibus. São Paulo, 23/05/73, p. 22. http://acervo.estadao.com.br/pagina/\#!/19730325-30057-nac-0022-999-22-not/ tela/fullscreen. Accessed on: 5 Jul. 2018.

[16] Ceneviva, C., Memória da Curitiba Urbana, IPPUC: Curitiba, 1990.

[17] Camargo, D., A História do Sistema de Transporte Coletivo de Curitiba (1887 / 2000), Travessia dos Editores: Curitiba, s/d.

[18] Dely, R. \& Okikawa, M., Curitiba: o fazimento de uma cidade, Banquinho: Curitiba, 2016.

[19] Georghiou, L., Effective Innovation Policies for Europe-The Missing Demand-Side, Economic Council of Finland: Finland, 2006. 